\title{
Insulin-like growth factor binding protein-6 inhibits prostate cancer cell proliferation: implication for anticancer effect of diethylstilbestrol in hormone refractory prostate cancer
}

\author{
H Koike', K Ito', Y Takezawa', T Oyama², H Yamanaka' and K Suzuki', \\ 'Department of Urology, Gunma University Graduate School of Medicine, 3-39-22 Showa-machi, Maeabshi, Gunma 37I851 I, Japan; '2Department of \\ Tumor Pathology, Gunma University Graduate School of Medicine, 3-39-22 Showa-machi, Maeabshi, Gunma 37I85 II, Japan
}

Diethylstilbestrol (DES) is a synthetic oestrogen, and its anticancer effects are exerted in androgen-dependent prostate cancer. The administration of DES decreases serum testosterone to castration levels. However, in androgen-independent prostate cancer patients, who are already orchiectomised, the administration of DES improves symptoms and decreases prostate-specific antigen (PSA). The mechanisms responsible for these direct inhibitory effects have been explained as biological actions not mediated by oestrogen receptors. We assessed the gene expression profiles of prostate cancer cells treated with DES, and investigated direct inhibitory effects of DES. DES inhibited the proliferation of LNCaP and PC-3 cells. CDNA microarray analysis showed that expression of many genes was downregulated by DES. However, insulin-like growth factor binding protein 6 (IGFBP-6) gene expression levels were upregulated in PC-3 cells. IGFBP-6 gene expression and protein levels significantly increased after DES treatment. Recombinant IGFBP-6 inhibited cell proliferation, and the inhibitory effect of DES was neutralised by anti-IGFBP-6 antibody. From the immunohistochemical analysis of IGFBP-6 using biopsy samples from androgen-independent prostate cancer, we found IGFBP-6 expression in androgen independent prostate cancer, and that DES treatment increased the IGFBP-6 staining intensity of the cancer cells in one sample. These findings suggested that DES induces IGFBP-6, which inhibits cell proliferation in an androgen-independent prostate cancer cell line, PC-3. IGFBP-6 therefore might be involved in the direct effects of DES in androgen-independent prostate cancer.

British Journal of Cancer (2005) 92, I538- 1544. doi: I0.1038/sj.bjc.6602520 www.bjcancer.com

(C) 2005 Cancer Research UK

Keywords: diethylstilbestrol; IGFBP-6; prostate cancer

Diethylstilbestrol (DES) is a synthetic oestrogen used in the treatment of advanced human prostate cancer (Ferro et al, 1989), and diethylstilbestrol diphosphate (DESdP) is a nontoxic prodrug form of DES (Flocks et al, 1955; Abramson et al, 1982). The palliative effects of DESdP administered to advanced-, hormoneinsensitive prostate cancer patients are well known (Flocks et al, 1955; Colapinto et al, 1961; Band et al, 1973; Droz et al, 1994; Takezawa et al, 2001). DESdP relieves bone pain in the majority of patients with metastatic prostate cancer who receive therapy (Hawtrey et al, 1974; Takezawa et al, 2001).

The administration of oestrogenic analogues causes the suppression of luteinising hormone-releasing-factor stimulation of the pituitary gland (Paulson, 1984). In addition, the subsequent reduction of testosterone synthesis induces anorchid levels of circulating serum testosterone (Paulson, 1984). The beneficial effect of DES therapy for previously orchiectomised patients, however, indicates that DES may not operate solely through the pituitary-gonadal axis. Several studies have sought to define the mode of DES action on a cellular level. DES treatment inhibits

*Correspondence: Dr K Suzuki; E-mail: kazu@showa.gunma-u.ac.jp Received 20 August 2004; revised 22 February 2005; accepted 22 February 2005 the growth of primary cultures derived from benign hyperplasia and prostate carcinoma samples (Brehmer et al, 1972) as well as prostate cancer cell lines (Schulz et al, 1990). Intracellular localisation studies of DES inhibition have targeted mitochondrial adenosine triphosphate synthase (McEnery et al, 1989), respiratory chain enzymes (Schulz et al, 1990), and microtubules (Hartley et al, 1985; Yokota et al, 1994) as sites of action. Robertson et al (1996) reported that DES inhibits proliferation of androgendependent and androgen-independent human prostate cancer cell lines by promoting cell cycle arrest, inducing apoptosis through a mechanism not mediated by estrogen receptors. However, the direct effects of DES are unclear. The aim of this study was to investigate the direct effects of DES in terms of gene expression, and to characterise the biological significance of specific genes involved in these effects.

\section{MATERIALS AND METHODS}

\section{Cell and chemicals}

The human prostate cancer cell lines LNCaP and PC-3 were purchased from Dainippon Pharmaceutical (Tokyo, Japan) and cultured in RPMI (Sigma, St Louis, MO, USA) supplemented with 
$10 \%$ fetal calf serum (FCS) (Moregate, Bulimba, Australia). DES (Sigma) was dissolved in DMSO, and recombinant insulin-like growth factor binding protein 6 (IGFBP-6) (Genzyme-techne, Minnesota, USA) was resuspended with PBS and stored at $-70^{\circ} \mathrm{C}$. Neutralising goat anti-IGFBP-6-antibody (Genzyme-techne), rabbit polyclonal anti-IGFBP-6-antibody (Austral biologicals, CA, USA) and normal goat IgG (Genzyme-techne) were resuspended with water and stored at $-70^{\circ} \mathrm{C}$, and MTT was purchased from Sigma and dissolved in water at $10 \mathrm{mg} \mathrm{ml}^{-1}$.

\section{Proliferation assay of human prostate cancer cells}

Approximately $5 \times 10^{3}$ LNCaP cells per well or $1 \times 10^{4}$ PC- 3 cells per well were incubated with $100 \mu \mathrm{l}$ of culture medium (CM) for $24 \mathrm{~h}$ at $37^{\circ} \mathrm{C}$ in a $5 \% \mathrm{CO}_{2}$ atmosphere. Thereafter, the $\mathrm{CM}$ was aspirated and the cells were incubated with $\mathrm{CM}$ containing various concentrations of DES, IGFBP-6, neutralising anti-IGFBP-6-antibody or normal goat IgG followed by a $4 \mathrm{~h}$ pulse of $50 \mu \mathrm{g}$ of MTT (Sigma). Isopropanol with $0.04 \mathrm{~N}$ hydrochloric acid $(100 \mu \mathrm{l})$ was added to lyse the cells. Colour development at a wavelength of $540 \mathrm{nM}$ was measured by a Microplate Readers SOFTmax-J enzyme-linked immumosorbent assay reader (Molecular Devices, Sunnyvale, CA, USA).

\section{DNA gel electrophoresis}

LNCaP and PC-3 cells treated with various concentrations of DES for $72 \mathrm{~h}$ were harvested by trypsin treatment. Genomic DNA was extracted using Wizard DNA extraction kit (Promega, Madison, WI, USA). DNA pellets were resuspended in distilled water and loaded in a $1.0 \%$ agarose gel. DNA was electrophoresed for $1.5 \mathrm{~h}$ at $10 \mathrm{~V} \mathrm{~cm}^{-1}$. Gels were stained with ethidium bromide (Sigma) and visualised under UV light.

\section{cDNA microarray analysis of the gene expression profiles of LNCaP and PC-3 cells}

cDNA microarray analysis of the gene expression profiles of LNCaP and PC-3 cells were performed according to previously described method (Suzuki et al, 2002). The cells were cultured in CM with $50 \mu \mathrm{M}$ DES for $48 \mathrm{~h}$, after which total RNA was extracted using an RNeasy Kit (Qiagen, Valencia, CA, USA) and treated with DNase I (Invitrogen, Carlsbad, CA, USA). In total, $50 \mu \mathrm{g}$ of DNase I treated total RNA was reverse-transcribed in the presence of $35 \mu \mathrm{M}$ Cy3-dUTP or Cy5-dUTP (Amersham Pharmacia, Piscataway, NJ, USA) and $10 \times$ lowT dNTP mix ( $5 \mathrm{~mm}$ dATP, $5 \mathrm{~mm}$ dGTP, $5 \mathrm{~mm}$ dCTP, 2 mm dTTP) using an RNA Fluorescence Labelling Core Kit (Takara, Tokyo, Japan). In total, 100 pg of $\lambda$ polyA + RNA (Takara) was added as a positive control. Unincorporated nucleotides and salts were removed by chromatography with a Centrisep (Princeton Separations, Adelphia, JN, USA). The Cy3 or Cy5 labelled cDNA after purification was mixed, and $30 \mu \mathrm{g}$ of human Cot I DNA (Invitrogen), $16 \mu \mathrm{g}$ of poly-dA (Amersham Phamacia) and $20 \mu \mathrm{g}$ of yeast tRNA (Sigma) were added to reduce nonspecific binding. The probes were resuspended in $10 \mu \mathrm{l}$ of hybridisation solution consisting of $6 \times$ SSC, $0.2 \%$ SDS and $5 \times$ Denhardt's solution (Invitrogen), and incubated at $98^{\circ} \mathrm{C}$ for $2 \mathrm{~min}$ and then $4^{\circ} \mathrm{C}$ for $10 \mathrm{~s}$. An IntelliGene ${ }^{\mathrm{TM}}$ Human Cancer CHIP Version 2.1 (Takara) glass slide was treated with prehybridisation solution consisting of $6 \times$ SSC, $0.2 \%$ SDS, $5 \times$ Denhardt's solution and $1 \mathrm{mg} \mathrm{ml}^{-1}$ denatured salmon sperm DNA (Invitrogen). The denatured probe was placed onto the glass slide with a coverslip, and hybridisation was performed at $65^{\circ} \mathrm{C}$ for $15 \mathrm{~h}$. The slides were then washed twice for $30 \mathrm{~min}$ in $2 \times \mathrm{SSC}$ at $55^{\circ} \mathrm{C}$, $5 \mathrm{~min}$ in $2 \times \mathrm{SSC}$ at $65^{\circ} \mathrm{C}$ and $5 \mathrm{~min}$ in $0.05 \times \mathrm{SSC}$ at room temperature.

The fluorescence intensities of the immobilised targets were measured using an Affymetrix Array Scanner 418 (Affymetrix,
Santa Clara, CA, USA). The two fluorescent images (Cy3 and Cy5) were separately scanned and the resulting imaging files were saved. The fluorescence intensities were analysed using the imaging software ImaGene ${ }^{\mathrm{TM}}$ ver 3.0 (BioDiscovery, Los Angeles, CA, USA). IntelliGene $^{\mathrm{TM}}$ Human Cancer CHIP ver 2.1 (Takara) carries 557 genes related to cancer (URL: http://www.takara.co.jp/ bio/goods/ new/new6/ new6-7.htm) and contains the following control spots: housekeeping genes: beta-actin; Uba80 mRNA for ubiquitin; phospholipase A2; glyceraldehydes-3-phosphate dehydrogenase (GAPDH); tubulin, alpha2; major histocompatibility complex, class I, A; ribosomal protein S5; general transcripton factor IIB; hexokinase 1 F0; DNA from a non-human species: lambda-A, lambda-B, lambda-C, lambda-D, lambda-E, pUC19, E.coli ompA, E.coli ftsZ, Arabidopsis chlorophyll $a b$ binding protein. The normalisation constant from 76 spots of 12 housekeeping genes was used to calculate the calibrated ratio for every cDNA spot within the image. We then calculated the differential expression ratios from two independent experiments and omitted spots for which the fluorescence intensities of $\mathrm{Cy} 3$ and $\mathrm{Cy} 5$ were less than 2000.

\section{Quantification of mRNA levels}

Quantification of transcript levels was performed using a Light Cycler (Roche Diagnostics, Indianapolis, IN, USA) according to the manufacturer's protocol and previous reports (ICJ, ACR). LNCaP cells were cultured in CM with $50 \mu \mathrm{M} \mathrm{DES}$, and PC-3 cells were culutured in CM with 12.5-50 $\mu \mathrm{M}$ DES for $48 \mathrm{~h}$. Total RNA was then extracted as described above and $2 \mu \mathrm{g}$ of this was reverse transcribed using random primers (Invitrogen), according to the manufacturer's protocol. Amplification was performed in $18 \mu \mathrm{l}$ of QuantiTect SYBR Green PCR Master MIX (Qiagen) using $2 \mu \mathrm{l}$ of cDNA and forward and reverse primers. Next, PCR was performed for one cycle of $15 \mathrm{~min}$ at $95^{\circ} \mathrm{C}$ followed by 50 cycles of $15 \mathrm{~s}$ at $94^{\circ} \mathrm{C}$, $20 \mathrm{~s}$ at $60^{\circ} \mathrm{C}$ and $15 \mathrm{~s}$ at $72^{\circ} \mathrm{C}$, with fluorescence detection being carried out at $72^{\circ} \mathrm{C}$ after each cycle. After the final cycle, meltingpoint analysis of all samples and controls was performed from 65 to $95^{\circ} \mathrm{C}$. Absolute quantification of IGFBP- 6 gene levels was performed according to a previously described method (Suzuki et al, 2002). For standard curve generation, PCR products of target genes (known amounts) were used for template DNA, and for the internal control 18s ribosomal RNA (rRNA) transcript levels were used. Gene expression levels were expressed as fold changes of those of the controls. The sequences of the primers for IGFBP-6 and 18s rRNA were as follows: IGFBP-6: forward, 5'-AGG ATG TGA ACC GCA GAG AC-3', reverse, 5'-GGT AGA AGC CTC GAT GGT CA-3'; 18 s rRNA: forward, 5'-CGG CTA CCA CAT CCA AGG AA-3', reverse, 5'-GCT GGA ATT ACC GCG GCT GC-3'.

\section{Detection of IGFBP-6 protein by Western blotting}

Detection of IGFBP-6 protein was performed according to modification of a previously described method (Hasumi et al, 2003). Equal amounts of proteins $(100 \mu \mathrm{g})$ from PC-3 cells were electrophoresed on a 5-20\% SDS-polyacrylamide gel and transferred onto a nitrocellulose membrane. After blocking, the membrane was reacted with anti-IGFBP-6 antibody at a 1:500 dilution at room temperature for $1 \mathrm{~h}$. The membrane was then reacted with horseradish peroxidase-linked rabbit immunogloburin, and recombinant IGFBP-6 was visualised using an ECL detection system (Amersham Biosciences, Tokyo, Japan). Data were obtained from three experiments.

\section{Immunohistochemical analysis of IGFBP-6 in clinical tissues}

To investigate the direct effects of DESdP, we examined androgenindependent prostate cancer which initially responded favourably 

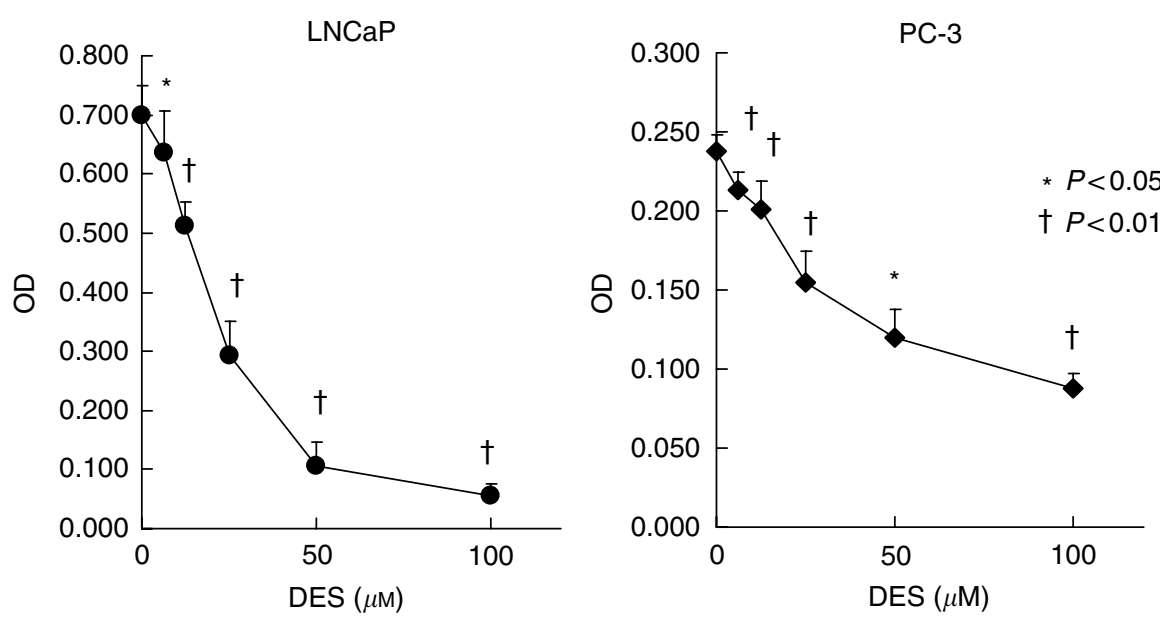

$72 \mathrm{~h}$ incubation MTT pulse during the final $4 \mathrm{~h}$ of incubation $($ mean + s.d.; $n=3)$

Figure I Inhibition of the proliferation of human prostate cancer cell lines LNCaP and PC-3 by diethylstilbestrol (DES). Cells were incubated for $24 \mathrm{~h}$, and thereafter CM was aspirated away and the cells were incubated with CM containing various concentrations of DES. After $72 \mathrm{~h}$, the number of viable cells was measured by MTT assay. Optical densities (OD) of cell lysates were measured at a wavelength of $540 \mathrm{~nm}$. The values are expressed as means $+\mathrm{s} . \mathrm{d}$. $(n=3)$, and the $P$-values were $<0.05(*)$ and $<0.01(\dagger)$.

to primary hormonal therapy, but then showed increases in prostate-specific antigen (PSA) levels or clinical symptoms or new lesions during treatment (Takezawa et al, 2001). Diethylstilbestrol diphosphate (DESdP) at $250 \mathrm{mg} \mathrm{day}^{-1}$ was dissolved in $500 \mathrm{ml}$ of physiological saline and intravenously infused for 28 days. PSA levels were measured before and 28 days after DESdP administration was started by enzyme immunoassay (EIA) (TOSOH-II PA kit, Tosoh Tokyo, Japan). Before and after DESdP administration, a biopsy of the prostate was performed. Paraffin sections of $4-\mu \mathrm{m}$ thickness were cut from archival paraffin blocks containing representative histology of the lesion. An immunohistochemical study was then performed on the sections using the avidinbiotinylated peroxidase complex (ABC) method with rabbit polyclonal anti-IGFBP6 antibody (kindly provided by Dr J Martin, University of Sydney, St Leonards, Australia) at 1:2000 dilution. Briefly, paraffin sections were dewaxed with xylene and incubated with $0.3 \%$ hydrogen peroxide in absolute methanol to block endogenous peroxidase activity. Antigen-retrieval was then carried out by autoclave-heating for $5 \mathrm{~min}$. To avoid nonspecific staining, the sections were incubated with $10 \%$ normal goat serum for $30 \mathrm{~min}$ at room temperature and were then treated with primary antibodies at $4{ }^{\circ} \mathrm{C}$ overnight. After a thorough washing, the sections were incubated with the secondary biotinylated anti-rabbit IgG (Vector Laboratories, CA, USA) for $30 \mathrm{~min}$ at room temperature followed by the ABC complex (DakoCytomation Co. Ltd., Glostrup, Denmark) for $30 \mathrm{~min}$ at room temperature. Finally, the slides were visualised with a solution containing $0.02 \% 3,3^{\prime}$-diaminobenzidine tetrahydrochloride and $0.005 \% \mathrm{H}_{2} \mathrm{O}_{2}$, followed by light counterstaining with haematoxylin.

\section{RESULTS}

DES induces apoptosis in prostate cancer cells, and so we first performed a cell proliferation assay using MTT to examine the effect of DES on prostate cancer cell proliferation. Viable cell numbers of LNCaP and PC-3 cells were decreased after DES administration in a dose-dependent manner as shown in Figure 1. To confirm the occurrence of apoptosis, extracted genomic DNA from LNCaP and PC-3 cells were electrophoresed. As shown in

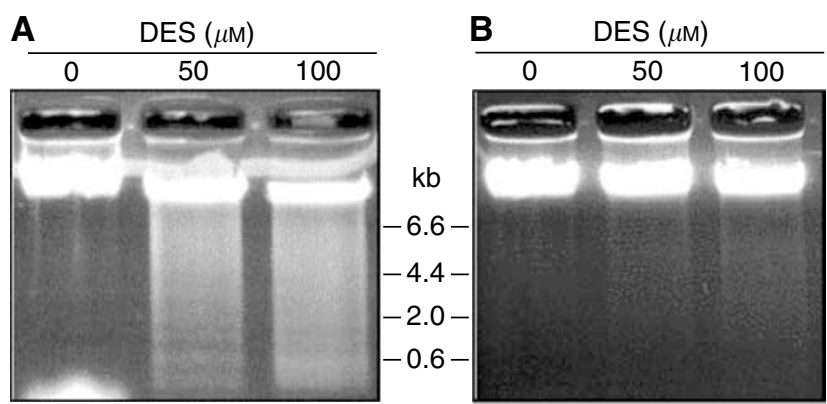

Figure 2 Gel electrophoresis of DNA of LNCaP and PC-3 treated with diethylstilbestrol (DES). Cells treated with various concentrations of DES for $72 \mathrm{~h}$ were harvested, and DNA was extracted. DNA was electrophoresed in a $1.0 \%$ agarose gel. DNA fragmentation was observed after DES treatment in both LNCaP $(\mathbf{A})$ and PC-3 cells $(\mathbf{B})$.

Figure 2, DNA fragmentation was observed in both cells after DES treatment; however, the extent of DNA fragmentation was low in PC-3 cells in comparison with that in LNCaP cells.

To screen for the effect of DES on prostate cancer cells, changes in gene expression in $\mathrm{LNCaP}$ and $\mathrm{PC}-3$ cells was assessed using a cDNA microarray. Two experiments showed that more than half of the genes fixed on the slide glass were downregulated greater than two-fold, and genes that were downregulated greater than five-fold are shown in Table 1. Genes involved in cell attachment/invasion, cell cycle, intracellular signalling, apoptosis and cell proliferation are included. On the other hand, only four genes were upregulated greater than two-fold after DES treatment as shown in Table 2. IGFBP-6 and keratin 19 gene expression levels were upregulated only in androgen-independent PC-3 cells. In clinical practice, DES exerted its antitumour effect on androgen-independent prostate cancer (Takezawa et al, 2001). Furthermore, IGFBP-6 inhibited the proliferation of rhabdomyosarcoma cells (Gallicchio et al, 2001). These findings prompted us to study the effect of DES and IGFBP- 6 on androgen-independent prostate cancer PC-3 cells. 
Table I Gene List: reduced after DES treatment

\begin{tabular}{|c|c|c|c|c|}
\hline Category & GenBank Acc. No. & Gene name & LNCaP & PC-3 \\
\hline Cell cycle & $\begin{array}{l}X 05360 \\
S 72008 \\
\times 51688 \\
M 74091 \\
\times 77784 \\
\cup 47414 \\
X 17644\end{array}$ & $\begin{array}{l}\text { Cell division cycle } 2 \\
\text { Cell division cycle } 10 \\
\text { Cyclin A2 } \\
\text { Cyclin C } \\
\text { Cyclin G1 } \\
\text { Cyclin G2 } \\
\text { G1 to G2 phase transition I }\end{array}$ & $\begin{array}{l}0 \\
\bullet \\
\bullet \\
0 \\
0 \\
0 \\
0\end{array}$ & $\begin{array}{l}0 \\
0 \\
0 \\
0 \\
0\end{array}$ \\
\hline Intracellular signalling & $\begin{array}{l}\text { AL03507I } \\
\text { X80692 } \\
\text { L35263 } \\
\text { LI I } 284 \\
\text { M97935 }\end{array}$ & $\begin{array}{l}\text { MAP kinase I } \\
\text { MAP kinase } 6 \\
\text { MAP kinase I4 } \\
\text { MAPK kinase I } \\
\text { STAT- I, 9I kDa }\end{array}$ & $\begin{array}{l}0 \\
0 \\
\bullet \\
0 \\
0\end{array}$ & $\begin{array}{l}0 \\
0 \\
0 \\
0 \\
0\end{array}$ \\
\hline Others & $\begin{array}{l}j 04088 \\
\text { MI5796 }\end{array}$ & $\begin{array}{l}\text { Topoisomerase (DNA) II, alpha } \\
\text { PCNA }\end{array}$ & $\ddot{0}$ & - \\
\hline
\end{tabular}

- indicates that the gene expression level was reduced more than five-fold after DES treatment.

Table 2 Gene list: elevated after DES treatment

\begin{tabular}{llll}
\hline $\begin{array}{c}\text { GenBank } \\
\text { Acc. No. }\end{array}$ & Gene name & LNCaP & PC-3 \\
\hline D86962 & Growth factor receptor-bound protein 10 & - \\
X57351 & IFN induced transmembrane protein 2 & \\
NM002178 & Insulin like growth factor binding protein-6 & \\
Y00503 & Keratin 19 &
\end{tabular}

- indicates that the gene expression level was elevated more than two-fold after DES treatment

To confirm the gene expression levels of IGFBP-6 in LNCaP and PC-3 cells, quantitative real-time PCR was performed. Basal expression levels of IGFBP-6 in LNCaP cells were about 20-fold lower than those in PC-3 (data not shown). After incubation with $50 \mu \mathrm{m}$ DES for $48 \mathrm{~h}$, IGFBP-6 gene expression levels in LNCaP cells showed no significant differences in comparison with the controls (data not shown). In PC-3 cells, IGFBP-6 gene expression levels significantly increased after DES treatment in a dose-dependent manner as shown in Figure 3. Western blot analysis showed that IGFBP-6 protein levels significantly increased in a dose-dependent manner as shown in Figure 4.

We next studied the effect of recombinant IGFBP-6 on prostate cancer cells. Although low-dose IGFBP-6 (62.5-125 $\left.\mathrm{ng} \mathrm{ml}^{-1}\right)$ did not affect cell proliferation, high-dose IGFBP-6 (250$1000 \mathrm{ng} \mathrm{ml}^{-1}$ ) inhibited cell proliferation as shown in Figure 5. After incubating the PC-3 cells with $800 \mathrm{ng} \mathrm{ml}^{-1}$ recombinant IGFBP-6, $20-30 \mu \mathrm{g} \mathrm{ml}^{-1}$ anti-IGFBP-6 antibody neutralised the inhibitory effects of cell proliferation. However, 5-10 $\mu \mathrm{g} \mathrm{ml}^{-1}$ antiIGFBP-6 antibody did not significantly neutralise this effect (Figure 6). Finally, we examined the effect of neutralising antiIGFBP- 6 antibody on DES treated PC-3 cells. Low-dose antibody $\left(10 \mu \mathrm{g} \mathrm{ml}^{-1}\right)$ did not show a significant effect on cell proliferation,

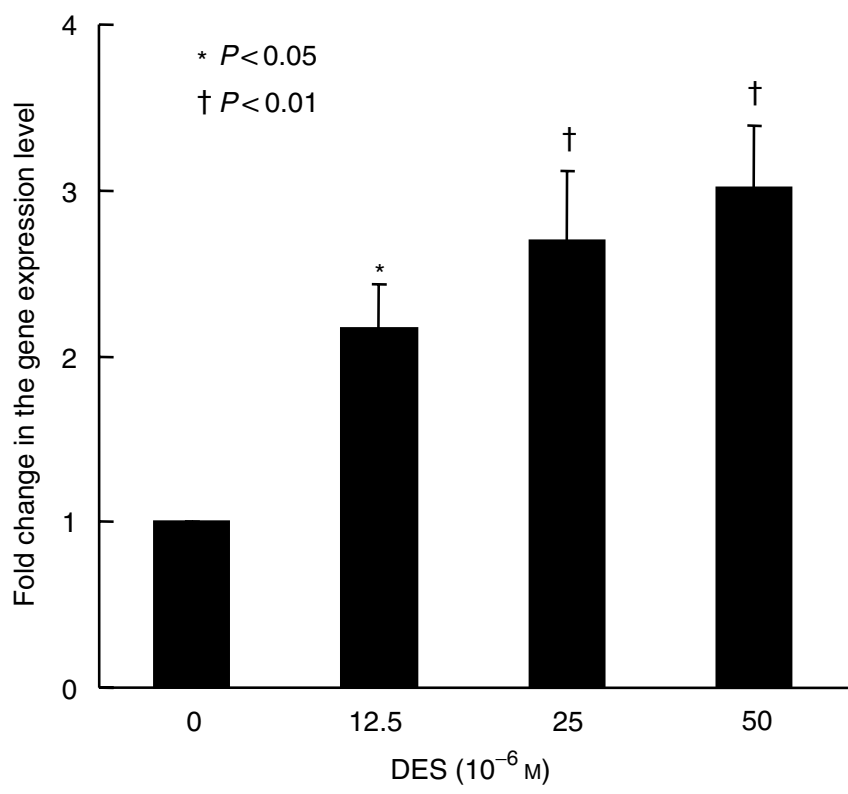

$48 \mathrm{~h}$ incubation $\quad($ mean + s.d. $n=3)$

Figure 3 Insulin-like growth factor binding protein-6 (IGFBP-6) gene expression levels in PC-3 cells. Transcript levels were measured by quantitative real-time PCR after treatment with various concentrations of DES. I8s ribosomal RNA transcript levels were used for the internal control, and gene expression levels were expressed as fold changes relative to those of the controls. IGFBP-6 gene expression was significantly increased after DES treatment in a dose-dependent manner in PC-3 cells. The values are expressed as means + s.d. $(n=3)$, and the $P$-values were $<0.05\left(^{*}\right)$ and $<0.0$ I ( $\dagger$ ) 


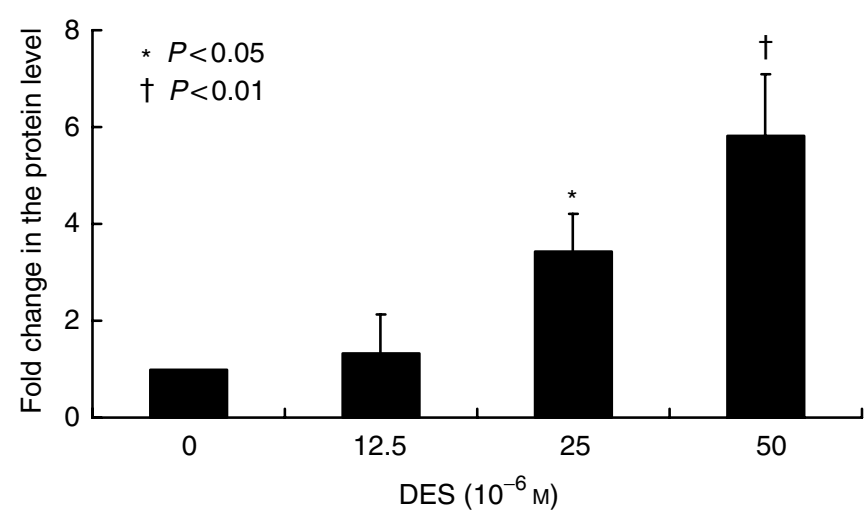

$48 \mathrm{~h}$ incubation (mean + s.d.; $n=3)$

Figure 4 Insulin-like growth factor binding protein-6 (IGFBP-6) protein levels in PC-3 cells. Protein levels were measured by Western blot analysis after treatment with various concentrations of DES. Proteins levels were expressed as fold changes. IGFBP-6 protein expression was significantly increased after DES treatment in a dose-dependent manner in PC-3 cells. The values were expressed as means + s.d. $(n=3)$, and the $P$-values were $<0.05(*)$ and $<0.01(\dagger)$.

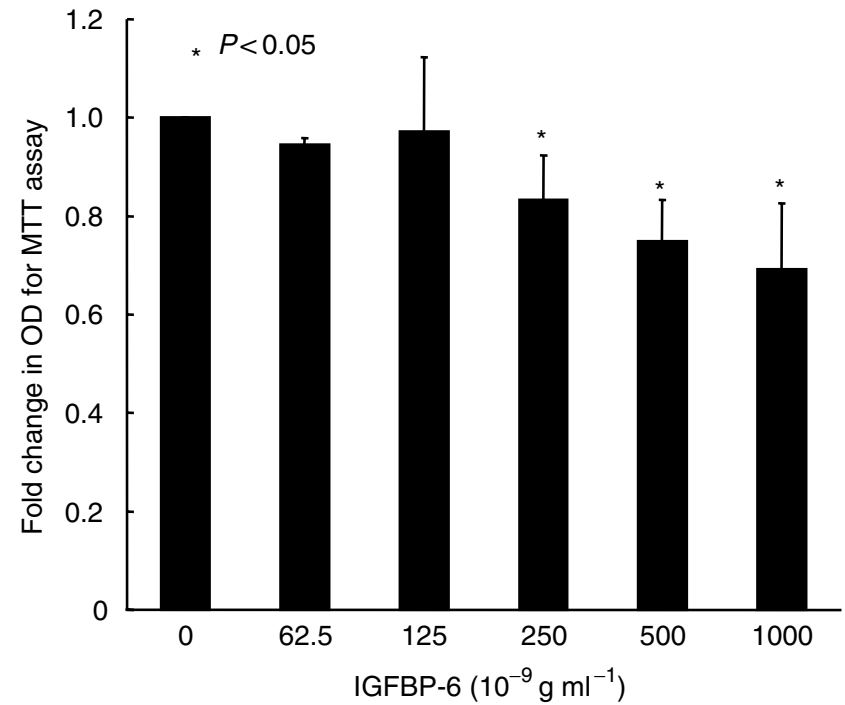

$48 \mathrm{~h}$ incubation MTT pulse during the final $4 \mathrm{~h}$ of incubation $($ mean + s.d.; $n=3)$

Figure 5 Inhibition of proliferation of human prostate cancer PC-3 cells by recombinant IGFBP-6. Cells were incubated for $24 \mathrm{~h}$, and thereafter CM was aspirated away and the cells were incubated with CM containing various concentrations of IGFBP-6. After $48 \mathrm{~h}$, the viable cell number was measured by MTT assay. The optical density (OD) of the cell lysates is expressed as the fold change. Recombinant IGFBP-6 inhibited the proliferation of PC-3 cells in a dose-dependent manner. The values are expressed as means + s.d. $(n=3)$, and the $P$-values were $<0.05$ (*).

but, cell proliferation was significantly upregulated with incubation with high-dose antibody $\left(30 \mu \mathrm{g} \mathrm{ml}^{-1}\right)$ as shown in Figure 7. Normal goat IgG did not affect on cell proliferation, as shown in Figures 6 and 7.

Clinically, DESdP treatment decreased PSA levels in all patients (Takezawa et al, 2001). In the prostate biopsy tissues before and after DES-dP treatment, cancer cells were detected in four patients. IGFBP-6 expression was examined by immunohistochemical staining, and was visible in the cytoplasm of cancer cells in the

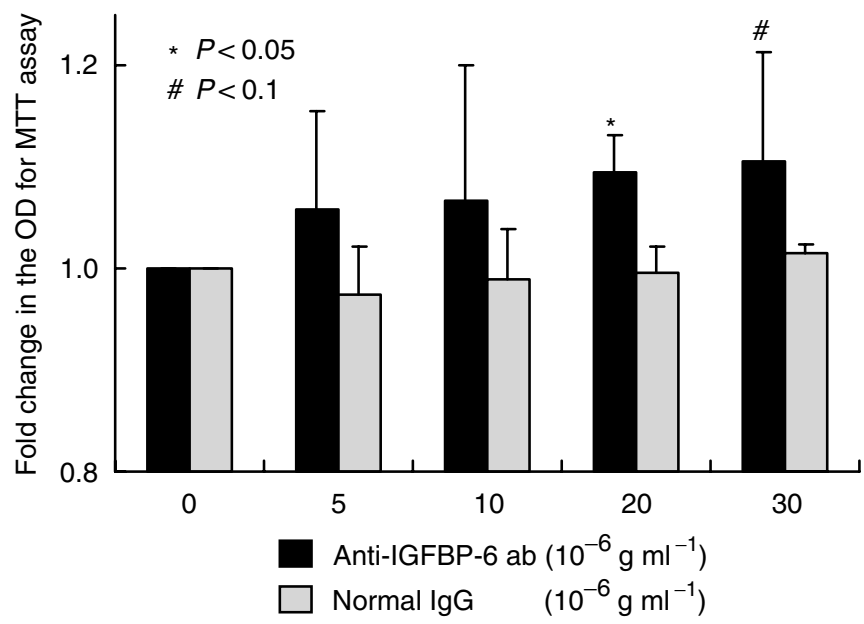

$48 \mathrm{~h}$ incubation with $800 \mathrm{ng} \mathrm{ml}^{-1}$ IGFBP-6

MTT pulse during final $4 \mathrm{~h}$ of incubation (mean + s.d.; $n=3$ )

Figure 6 Effects of IGFBP-6 and anti-IGFBP-6 antibody on PC-3 cell proliferation. Cells were incubated for $24 \mathrm{~h}$, and thereafter $\mathrm{CM}$ was aspirated away. After $48 \mathrm{~h}$ of incubation of PC-3 cells with $800 \mathrm{ng} \mathrm{ml}^{-1}$ recombinant IGFBP-6 and various concentrations of anti-IGFBP-6 or normal goat $\mathrm{lgG}$, the viable cell number was measured by $M T T$ assay. The optical density (OD) of the cell lysates was expressed as the fold change. In total, $20-30 \mu \mathrm{g} \mathrm{ml}^{-1}$ of anti-IGFBP-6 antibody significantly neutralised the inhibitory effects of cell proliferation. The values are expressed as means + s.d. $(n=3)$, and the P-values were $<0.05$ (*) and $<0.1$ (\#)

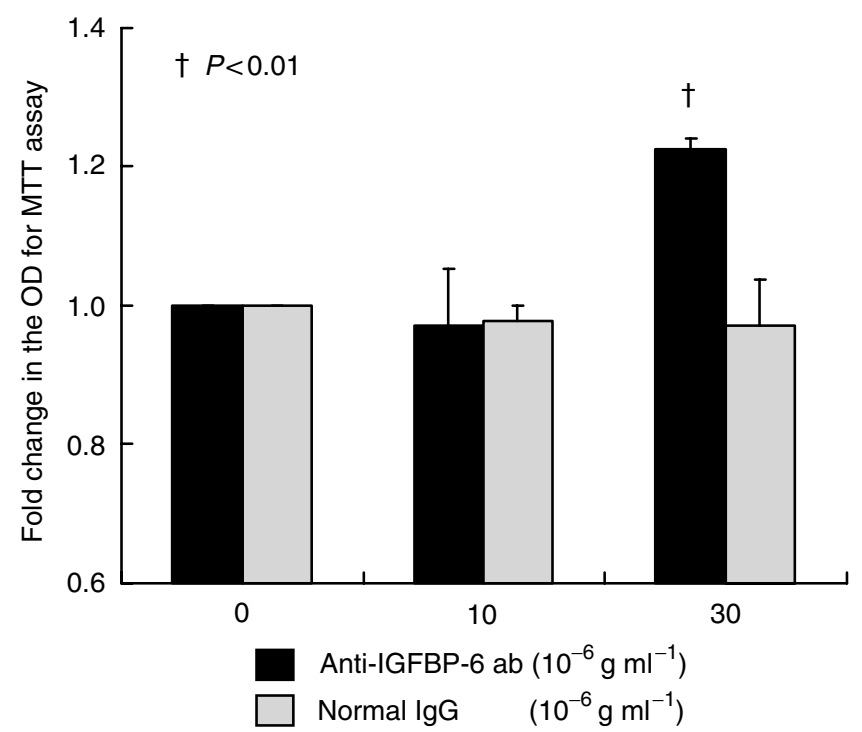

$48 \mathrm{~h}$ incubation with $6.25 \mu \mathrm{m}$ DES

MTT pulse during the final $4 \mathrm{~h}$ of incubation (mean + s.d.; $n=3$ )

Figure 7 Effect of neutralising anti-IGFBP-6 antibody on DES-treated PC-3 cells. Cells were incubated for $24 \mathrm{~h}$, and thereafter CM was aspirated away. After $48 \mathrm{~h}$ incubation of PC-3 cells with $6.25 \mu \mathrm{M}$ DES and various concentrations of anti-IGFBP-6 antibody or normal goat lgG, the viable cell number was measured by MTT assay. The optical density (OD) of the cell lysates was expressed as the fold change. Cell proliferation was significantly upregulated by incubation with high-dose antibody $\left(30 \mu \mathrm{g} \mathrm{ml}^{-1}\right)$. AntiIGFBP-6 antibody inhibited DES-induced cell growth suppression. The values are expressed as means + s.d. $(n=3)$, and the $P$-values were $<0.0$ I $(\dagger)$.

organ. Before treatment with DESdP, IGFBP-6 expression was positive in three patients. In one of them (patient \#1), IGFBP-6 expression increased after treatment with DESdP, and in others 
Table 3 Clinical and immunohistchemical data of androgen-independent prostate cancer patients

\begin{tabular}{|c|c|c|c|c|c|}
\hline \multirow[b]{2}{*}{ Patient } & \multirow[b]{2}{*}{ Pathology at diagnosis } & \multicolumn{2}{|c|}{ Immunohistochemical analysis of IGFBP6 in prostate biopsy tissues } & \multicolumn{2}{|c|}{ PSA $\left(\mathrm{ng} \mathrm{dl}^{-1}\right)$} \\
\hline & & Before DES-dP treatment & After DES-dP treatment & Before & After \\
\hline 2 & Moderately diff. & Positive & Positive & 417 & 194 \\
\hline 3 & Moderately diff. & No cancer cells & No cancer cells & 25.3 & 9.3 \\
\hline 4 & Moderately diff. & No cancer cells & No cancer cells & 166 & 112 \\
\hline 5 & Poorly diff. & No cancer cells & No cancer cells & 35.6 & 2.4 \\
\hline
\end{tabular}

\section{A}

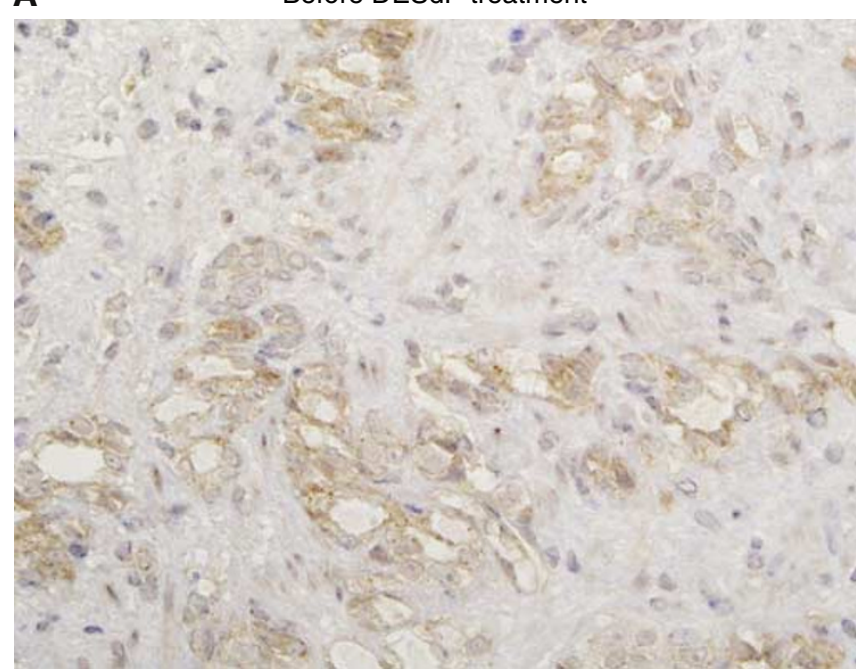

B

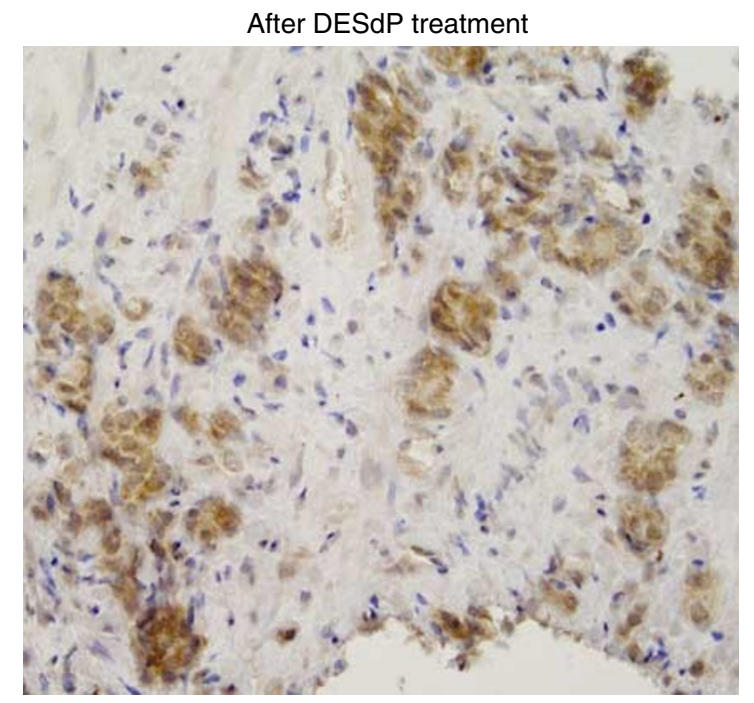

Figure 8 Immunohistochemical staining of IGFBP-6. IGFBP-6 was visible in the cytoplasm of cancer cells in the organ $(\mathbf{A})$. For one patient, DESdP treatment increased the IGFBP-6 staining intensity in cancer cells (B). The immunostained section in (B) is from the same patient as that shown in (A). Cells that stained positively for IGFBP-6 are brown in colour.

(patients \#2 and \#7) it was not changed (Table 3). DESdP treatment increased the IGFBP- 6 staining intensity in cancer cells of patient $\# 1$ as shown in Figure 8.

\section{DISCUSSION}

We first confirmed the antiproliferative and apoptosis-inducing effects of DES on prostate cancer cells. Cell proliferation of LNCaP or PC-3 cells was inhibited by DES in a dose-dependent manner in combination with cellular apoptosis. This is consistent with results reported by Robertson et al (1996), who examined the induction of apoptosis by DES in PC-3 cells. They concluded that the direct cytotoxic effects of DES in prostate cancer cells are estrogen receptor-independent and involve the promotion of cell cycle arrest and apoptosis.

Recently, gene expression profiles can be screened using a cDNA microarray, which provides important information on biological activities. We previously reported the gene expression profiles of LNCaP and PC-3 cells treated by genistein using a cDNA microarray, and found unique genes involved in the direct effects of genistein on prostate cancer cells (Suzuki et al, 2002). The present study showed that expression levels were downregulated for most genes. This downregulation reflects the suppressive effects of DES. However, the expression of IGFBP-6 and keratin 19 gene were upregulated in androgen-independent prostate cancer PC-3 cells. IGFBP-6 inhibits the proliferation of rhabdomyosarcoma cell lines (Gallicchio et al, 2001). Therefore, we characterised the biological action of IGFBP-6 in PC-3 cells. In rhabdomyosarcoma cells, IGFBP-6 inhibited cell proliferation in a dosedependent manner by inhibiting insulin-like growth factor II (IGF-II), which stimulates cell proliferation. Gallicchio et al concluded that IGFBP-6 exerts an inhibitory effect on the proliferation and survival of rhabdomyosarcoma cells in vitro. In the present study, the proliferation of PC-3 cells was inhibited by recombinant IGFBP-6 in a dose-dependent manner. We also found that DES administration induces IGFBP-6 at the mRNA and protein level. Furthermore, anti-IGFBP- 6 antibody antagonises the inhibitory effect of DES. Therefore, we speculate that IGFBP-6 is involved in the direct effect of DES.

IGFBP-6 is unique for its dramatically higher affinity for IGF-II (Bach et al, 1999), and is an inhibitor of IGF-II (Kiefer et al, 1992; Bach et al, 1994; Bach et al, 1999). IGF-II is an autocrine growth factor that affects neuroblastoma (Grellier et al, 2002) and rhabdomyosarcoma (Gallicchio et al, 2001) cells. In vivo, Grellier et al reported on the transplantation of human IGFBP-6expressing neuroblastoma cells in nude mice, and their results showed a lower incidence of xenografts, which also exhibited slower growth than those obtained using control cells (1998). IGFII was more strongly expressed in control tumours in this model. They concluded that excess IGFBP-6 displaces IGF-II from IGFBP2 , thus preventing it from potentiating the mitogenic action of IGFII (2002). Gallicchio et al (2001) also reported that IGFBP-6 dramatically inhibits xenograft growth of rhabdomyosarcoma cells.

In prostate cancer, Kimura reported that IGF-II occurred at the protein and RNA level in PC-3 cells without the occurrence of 
significant amounts of IGF-I protein in the conditioned media of these cell-lines. Furthermore, IGF-II stimulates the growth of PC-3 cells. Therefore, the autocrine activity of IGF-II may contribute in part to the proliferation of PC-3 cells (Kimura et al, 1996). Drivdahl reported that the upregulation of IGFBP-6 occurs in association with the activity of 1,25-dihydroxyvitamin $\mathrm{D}_{3}$ in prostate cancer cells, and suggested a role for IGFBP-6 in the suppression of prostate tumour cell growth (Drivdahl et al, 1995). This prompted us to investigate the effect of IGFBP- 6 on androgenindependent prostate cancer PC-3 cells. The present findings are the first observations to confirm the inhibitory effect of IGFBP-6 on PC-3 cells.

In clinical practice, we treated seven patients with androgenindependent prostate cancer with DESdP (Table 3). PSA levels decreased in all patients, and palliative effects were obtained. Viable cancer cells were confirmed by prostate needle biopsy specimens for four patients. Three of the four were positive for IGFBP-6 staining. For one patient, IGFBP-6 immunostaining was upregulated as shown in Figure 8. This suggests that upregulation of IGFBP-6 was observed in a part of patients with androgenindependent prostate cancer treated by DESdP. We considered that the heterogeneity of biological features of prostate cancer may have affected the present results.

\section{REFERENCES}

Abramson FP, Miller Jr HC (1982) Bioavailability, distribution and pharmacokinetics of diethylstilbestrol produced from stilphostrol. J Urol 128: 1336 - 1339

Bach LA (1999) Insulin-like growth factor binding protein-6: the'forgotten' binding protein. Horm Metab Res 31: 226-234

Bach LA, Hsieh S, Brown AL, Rechler MM (1994) Recombinant human insulin-like growth factor(IGF)-binding protein-6 inhibits IGF-II-induced differentiation of L6A1 myoblasts. Endocrinology 135: 2168-2176

Band PR, Banerjee TK, Patwardhan VC, Eid TC (1973) High-dose diethylstilbestrol diphosphate therapy of prostatic cancer after failure of standard doses of estrogens. Can Med Assoc J 109: 697-699

Brehmer B, Marquardt H, Madsen PO (1972) Growth and hormonal response of cells derived from carcinoma and hyperplasia of the prostate in monolayer cell culture. A possible in vitro model for clinical chemotherapy. J Urol 108: 890-896

Colapinto V, Aberhart C (1961) Clinical trial of massive stilbestrol diphosphate therapy in advanced carcinoma of the prostate. $\mathrm{Br} J$ Urol 33: $171-177$

Drivdahl RH, Loop SM, Andress DL, Ostenson RC (1995) IGF-binding proteins in human prostate tumor cells: expression and regulation by 1,25-dihydroxyvitamin D3. Prostate 26: $72-79$

Droz JP, De Smedt E, Kattan J, Keuppens F, Khoury S, Mahler C, Denis L (1994) Phase I trial of high-dose fosfestrol in hormone-refractory adenocarcinoma of the prostate. Prostate 24: 62-66

Ferro MA, Gillatt D, Symes MO, Smith PJ (1989) High-dose intravenous estrogen therapy in advanced prostatic carcinoma. Use of serum prostate-specific antigen to monitor response. Urology 34: 134-138

Flocks RH, Marberger H, Begley BJ, Hans M, Prendergast LJ (1955) Prostatic carcinoma:treatment of advanced cases with intravenous diethylstilbestrol diphosphate. J Urol 74: 549-551

Gallicchio MA, Kneen M, Hall C, Scott AM, Bach LA (2001) Overexpression of insulin-like growth factor binding protein-6 inhibits rhabdomyosarcoma growth in vivo. Int J Cancer 94: 645-651

Grellier P, Berrebi D, Peuchmaur M, Babajko S (2002) The IGF system in neuroblastoma xenografts: focus on IGF-binding protein-6. J Endocrinol 172: $467-476$

Hartley B, Deinum J, Wallin M (1985) Diethylstilbestrol induces metaphase arrest and inhibits microtubule assembly. Mutat Res 143: $231-235$
In conclusion, we found that many genes including cell attachment/invasion, cell cycle, intracellular signalling, apoptosis and cell proliferation genes, are downregulated after DES treatment in human prostate cancer LNCaP and PC-3 cells. However, IGFBP- 6 is upregulated at the mRNA and protein level in androgen-independent human prostate cancer PC-3 cells. rIGFBP6 inhibits PC-3 cell proliferation, and neutralising anti-IGFBP-6 antibody antagonises the inhibitory effect of DES in PC-3 cells. These finding suggest that IGFBP-6 might be involved in the direct effect of DES in androgen-independent human prostate cancer.

\section{ACKNOWLEDGEMENTS}

We greatly thank Dr J Martin, University of Sydney, St Leonards, Australia, for generously providing us the rabbit polyclonal antiIGFBP6 antibody. We also thank for Ms Naomi Takase for technical assistance. The present study was partly supported by a Grant-in-Aid for Scientific Research (Project No. 12470328) and a Grant-in-Aid for Exploratory Research (Project No. 14657403) from The Ministry of Education, Science, Sports and Culture.
Hasumi M, Suzuki K, Matsui H, Koike H, Ito K, Yamanaka H (2003) Regulation of metallothionein and zinc transporter expression in human prostate cancer cells and tissues. Cancer Lett 200: 187-195

Hawtrey CE, Welch Jr MJ, Schmidt JD, Culp DA, Flocks RH (1974) Paraplegia and paraparesis due to prostate cancer. Use of intravenous diethylstilbestrol diphosphate. Urology 4: 431-434

Kiefer MC, Schmid C, Waldvogel M, Schlapfer I, Futo E, Masiarz FR, Green K, Barr PJ, Zapf J (1992) Characterization of recombinant human insulin-like growth factor(IGF)-binding proteins 4,5 and 6 produced in yeast. J Biol Chem 267: 12692-12699

Kimura G, Kasuya J, Giannini S, Honda Y, Mohan S, Kawachi MH, Akimoto M, Yamaguti Y (1996) Insulin-like growth factor (IGF) system components in human prostatic cancer cell-lines: LNCaP, DU145, and PC-3 cells. Int J Urol 3: $39-46$

McEnery MW, Hullihen J, Pedersen PL (1989) F0 proton channel of rat liver mitochondria. Rapid purification of a functional complex and a study of its interaction with the unique probe diethylstilbestrol. J Biol Chem 264: $12029-12036$

Paulson DF (1984) Carcinoma of the prostate: the therapeutic dilemma. Annu Rev Med 35: $341-372$

Robertson CN, Roberson KM, Padilla GM, Brien ETO', Cook JM, Kim CS, Fine RL (1996) Induction of apoptosis by diethylstilbestrol in hormoneinsensitive prostate cancer cells. JNCI 88: 908-917

Schulz P, Link TA, Chaudhuri L, Fittler F (1990) Role of the mitochondrial bcl-complex in the cytotoxic action of diethylstilbestrol-diphosphate toward prostatic carcinoma calls. Cancer Res 50: 5008-5012

Suzuki K, Koike H, Matsui H, Ono Y, Hasumi M, Nakazato H, Okugi H, Sekine Y, Oki K, Ito K, Yamamoto T, Fuksbori Y, Kurokawa K, Yamanaka H (2002) Genistein, a soy isoflavone, induces glutathione peroxidase in the human prostate cancer cell lines LNCaP and PC-3. Int J Cancer 99: $846-852$

Takezawa Y, Nakata S, kobayashi M, kosaku N, Fukabori Y, Yamanaka H (2001) Moderate dose diethylstilbestrol diphosphate therapy in hormone refractory prostate cancer. Scand J Urol Nephrol 35: $283-287$

Yokota E, Ichinosei K, Sato Y (1994) Microtubule disruption induced by estradiol in estrogen receptor-positive and -negative human breast cancer cell lines. Carcinogenesis 15: 1875-1879 